\title{
Response of Four Shrub Species to Different Water Source Components in an Arid Environment
}

\author{
A. Wagner ${ }^{1}$, D. A. Devitt ${ }^{1}$, B. Bird ${ }^{1}$, R. Jasoni ${ }^{2} \&$ J. A. Arnone III ${ }^{2}$ \\ ${ }^{1}$ School of Life Sciences, University of Nevada Las Vegas, Las Vegas NV, USA \\ ${ }^{2}$ Desert Research Institute, Reno, NV, USA \\ Correspondence: D. A. Devitt, ${ }^{1}$ School of Life Sciences, University of Nevada Las Vegas, Las Vegas NV. E-mail: \\ dale.devitt@unlv.edu \\ Received: August 16, 2018 \\ Accepted: August 28, 2018 \\ Online Published: September 29, 2018 \\ doi:10.5539/enrr.v8n3p166 \\ URL: https://doi.org/10.5539/enrr.v8n3p166
}

\begin{abstract}
Shrubland species in the Great Basin (USA) depend on soil water recharged from precipitation and/or groundwater for survival and growth. Climate warming and possible basin water diversion could alter the amount and timing of water availability to these plants. The objective of this study was to quantify the extent to which each of four co-occurring shrub species, big sage [Artemisia tridentata], rabbitbrush [Ericameria nauseosus], greasewood [Sarcobatus vermiculatus] and shadscale [Atriplex confertifolia)) acquired water from different sources (precipitation, soil vadose zone and/or groundwater) during a growing season. Soil salinity increased linearly with depth over the upper $1.5 \mathrm{~m}$ of soil, with salinity ranging from 0.84 to $31.70 \mathrm{dSm}^{-1}$ in saturation extracts $\left(\mathrm{R}^{2}=0.78\right.$, $\mathrm{p}<0.001)$. Changes in soil water both with depth and time during the growing period indicated that all species accessed soil water from precipitation recharge. Evapotranspiration totals for the growing period exceeded total precipitation by $137 \mathrm{~mm}$, indicating that plants also used water stored deeper within the vadose zone and/or from groundwater (particularly) by the phreatophyte greasewood. $\delta^{18} \mathrm{O}$ in the soil solution declined linearly with depth over the upper $100 \mathrm{~cm}\left(\mathrm{R}^{2}=0.80, \mathrm{p}<0.001\right) . \delta^{18} \mathrm{O}$ values in greasewood corresponded closely to $\delta^{18} \mathrm{O}$ values measured deeper in the vadose zone and groundwater. Output from a mixing model indicated a decrease in groundwater reliance for greasewood from $30 \%$ in July to $2 \%$ in September, with a major shift to deeper soil water in the vadose zone (180 cm depth) (38\% in July to $97 \%$ in September). Our data suggested that the four shrub species at our site were able to coexist because of their different spatial, temporal, and physiological uses of available soil water, reflecting possible water resource partitioning based on differences in response to precipitation, ability to extract water at deeper depths and variable tolerance to elevated levels of soil salinity to access groundwater.
\end{abstract}

Keywords: evapotranspiration, groundwater, ${ }^{18} \mathrm{O}$, salinity, species differential soil water availability

\section{Introduction}

The composition and thus function of mixed shrublands in the valleys of the Great Basin (NV, USA) face an uncertain future because climate change and possible groundwater diversion threaten to impact phreatophytic and non-phreatophytic species. Warming temperatures have been documented for the Great Basin over the last century (Tang et al., 2014), with significant increases in annual minimum temperatures, leading to a decrease in the number of frost days. Climate models predict that the western United States will continue on a trend towards a warmer and dryer climate with temperature increases projected at 2 to $4{ }^{\circ} \mathrm{C}$ by 2050 , with 11 of 12 global models predicting significant drying (Barnett \& Pierce, 2008, McCabe \& Wolock, 2007, Christensen et al., 2004). Groundwater diversion in these shrubland areas has been approved although still contested in court, allowing groundwater to potentially be pumped from east central Nevada basins to southern Nevada for municipal use to compensate for projected decreases in water supplies from the Colorado River and continued population growth (SNWA, 2012). How shrublands in these basins will respond to water removal is unclear. However it is expected that increased environmental demand associated with precipitation currently in the $15-28 \mathrm{~cm}$ range will place increased stress on non-phreatophytes like big sage. Whereas, phreatophytes, like greasewood will be able to offset higher environmental demand by supplementing soil water extraction with groundwater extraction (Devitt et al., 2010, Devitt \& Bird, 2015). If groundwater pumping is significant and groundwater levels decline (Devitt \& Bird, 2015, Harrill \& Prudic, 1998), it is possible such plants could become decoupled from what is currently considered 
a reliable source of water (Steinwand et al., 2006, Devitt \& Bird, 2015). If this occurs phreatophytes would be forced to compete with non-phreatophytes to a greater extent for limited amounts of water in the vadose zone (Bush et al., 1992, Devitt \& Bird, 2015).

The Great Basin is a closed drainage basin with the majority of discharge as evapotranspiration, as such, soils within the upper vadose zone typically have elevated levels of soluble salts. Devitt and Bird (2015) estimated that chloride profiles in Snake Valley (NV) required over 10,000 years to form, indicating a tight balance between precipitation, evapotranspiration and drainage over an extended period of time. If phreatophytes are forced to rely more on upper vadose zone water, this might drive salinity levels higher, creating greater competition between halophytes and non halophytes (Rozema, 1995).

Research from Owens Valley, California demonstrated that groundwater pumping from a large natural basin decoupled phreatophytes from groundwater in four semi-arid plant communities in the Great Basin over the course of 13 years of pumping (Elmore et al., 2006). These researchers attributed this response to groundwater levels dropping below the root zone of the phreatophyitc vegetation. They further documented a shift from an ecosystem buffered from drought to one that was increasingly sensitive to small changes in precipitation. Chimmer and Cooper (2004) utilized stable isotopes to identify when phreatophytic shrubs shifted water uptake from the unsaturated vadose zone to groundwater, with the responses shown to be due to seasonal variations in soil water in storage and precipitation.

Steinwand et al. (2006) also documented various levels of dependence of shrub dominated plant communities on groundwater and suggested that the disappearance of diurnal fluctuations in daily groundwater levels signaled a decoupling from the groundwater. Devitt et al. (2010) developed an empirical relationship between eddy covariance evapotranspiration (ET) estimates with Landsat generated vegetation index (NDVI) values to make basin wide ET estimates. ET rates were highly correlated with plant cover within the phreatophytic area of the basin with ET totals exceeding precipitation in the study by 55-60 percent, a clear indication of deep vadose zone and/or groundwater extraction. In a later study, Devitt and Bird (2015) demonstrated that a lack of groundwater oscillations could be related to a textural change in the profile but when oscillations occurred they could be directly linked to changes in environmental demand and soil water content in the vadose zone.

The objectives of our study were (i) to assess soil water and plant water status of a mixed shrub plant community over a growing season in the Great Basin (approved for groundwater pumping and diversion) to determine if significant differences exist between the four species (greasewood, shadscale, ,rabbitbrush and big sage), (ii) evaluate $\delta^{18} \mathrm{O}$ in precipitation, groundwater, soil water and stem water over a growing season to assess which sources of water the shrub species were more dependent on, and (iii) based on soil salinity profiles and $\delta^{18} \mathrm{O}$ profiles in the vadose zone, assess if water resource partitioning might be occurring, influencing the ability of halophytes and non-halophytes to coexist..

\section{Methods and Materials}

Research was conducted in central Spring Valley, Nevada within the Great Basin Desert (USA). The site was situated at Easting: 717823.99, Northing: 4324555.44, at an elevation of 1,756 m. The site is part of the Nevada System of Higher Education's climate monitoring network called NevCAN (http://nevcan.dri.edu) with the site denoted as the Spring Valley salt desert shrubland site (Mensing et al., 2013). This site was selected because it closely represents the mixed shrubland plant communities that cover large areas of valley bottoms in the Great Basin, and because a groundwater monitoring well and an eddy covariance tower (to estimate ET) were in place. Soil texture at this site was classified as a loam in the upper $40 \mathrm{~cm}$, sandy clay loam between $40-80 \mathrm{~cm}$, transitioning to a classification of clay at a depth of $340 \mathrm{~cm}$ (Koonce, 2016).

Shrub cover of each of the four dominant species was assessed by measuring the surface area of each plant within four random $25 \times 25 \mathrm{~m}$ plots. The dominant species at this site based on percent cover (Table 1) were; big sage $(71.3 \%)$, greasewood $(19.2 \%)$, shadscale $(7.9 \%)$, and rabbitbrush $(1.6 \%)$. Greasewood has been classified as a phreatophyte, or groundwater user in the Great Basin (Devitt \& Bird, 2015), while big sage, rabbitbrush and shadscale have shallower root systems and are often found in areas where the water table is very deep (Reynolds et al., 1989, Nichols, 1994, Devitt personal observation), although at sites in CA rabbitbrush has been classified as a phreatophyte (Donovan et al., 1997). Three representative plants of each species were selected for monitoring. 
Table 1. Species growing at the experimental site along with $\%$ cover estimates

\begin{tabular}{lllll}
\hline Species & Scientific Name & \% Vegetative cover & \% Living Cover & Total site \% cover \\
\hline Greasewood & Sarcobatus vermiculatus & 19.2 & 17.4 & 45.4 \\
Bigsage & Artemisia tridentata & 71.3 & 56.4 & \\
Rabbitbrush & Ericameria nauseosus & 1.6 & 1.3 & \\
Shadscale & Atriplex confeertifolia & 7.9 & 7.0 & \\
\hline
\end{tabular}

Soil samples $(7.5 \mathrm{~cm}$ diameter auger) were collected in $10 \mathrm{~cm}$ increments to a depth of at least $220 \mathrm{~cm}$ under the canopy edge of each of the selected shrubs toward the end of the growing season. Soil salinity and chloride concentrations were measured in these soil samples to assess the relationship between water removal and salt buildup in the profiles. Each sample was placed in a plastic bag, sealed, and placed on ice and transported to the laboratory where all samples were stored at $4^{\circ} \mathrm{C}$. To determine salinity and chloride concentration in each soil sample, a saturation extract was performed on air dried soil subsamples (U.S. Salinity Laboratory 1954). To quantify soil salinity, the electrical conductivity $\left(\mathrm{EC}_{\mathrm{e}}\right)$ of the saturation extract was analyzed using an electrical conductivity bridge (Beckman Instruments, Fullerton CA) recorded in units of $\mathrm{dSm}^{-1}$ following the method of the U.S. Salinity Laboratory (1954). Chloride was analyzed with a chloride titrator (Haake Buchler digital chloridometer, San Diego, CA)

${ }^{18} \mathrm{O}$-isotopic composition of water in each soil sample, was measured using cryogenic distillation (Wagner, 2016) to calculate an isotopic profile against which we compared the ${ }^{18} \mathrm{O}$ signatures of xylem water extracted from stems of the selected shrubs throughout the growing season (e.g., Obrist et al., 2003). Groundwater was sampled during high and low groundwater periods from the monitoring well. Precipitation water was also collected during the growing season for ${ }^{18} \mathrm{O}$-isotopic analysis by placing a glass beaker filled with mineral oil to a depth of $5 \mathrm{~mm}$ inside an empty tipping bucket rain gauge. All of these samples, except stem xylem water, were analyzed at the Las Vegas Isotope Science Laboratory (University of Nevada, Las Vegas) on a Thermo Electron high-temperature Delta V Plus isotope ratio mass spectrometer (Lachniet, 2016 personal communication). The data were calibrated such that the values for Vienna Standard Mean Ocean Water (VSMOW) were $\delta \mathrm{D}=0, \delta{ }^{18} \mathrm{O}=0.0$, and Standard Light Antarctic Precipitation (SLAP) $\delta \mathrm{D}=-428$ and $\delta{ }^{18} \mathrm{O}=-55.5 \%$, respectively. Resulting precision for $\delta \mathrm{D}$ and $\delta{ }^{18} \mathrm{O}$ was better than 2.0 and $0.20 \%$, respectively (Lachniet, 2016, personal communication). Stem xylem water from mature stem samples (sampled randomly from the upper canopy) taken from each species were sealed on both ends with sealing film and then placed in small plastic vials and packed in dry ice and shipped to the University of Utah (Salt Lake City, UT) within 24 hours of sample collection. Stem xylem water was extracted using a cryogenic vacuum distillation method. The comparisons of the ${ }^{18} \mathrm{O}$ in the soil, precipitation, groundwater and stem xylem allowed for estimations of the fractional contribution from the different water sources for each species using a software program entitled IsoSource (http:/www.eoa.giv/wed/pages/models/stable Isotopes/ isosource/isource.htm) (Phillips et al., 2005).

A fully equipped eddy covariance "station" (Campbell Scientific Inc, Logan UT, USA) previously installed at the SV6 site allowed continuous quantification of ET during the growing season (Arnone et al., 2008). Data from all instruments were recorded with a datalogger (CR5000, Campbell Scientific) at a frequency of $10 \mathrm{~Hz}$ and stored on a compact flash card for post-processing Data from the EC station were downloaded monthly when instruments were checked and maintained. ET values were calculated using the methods described in Arnone et al. (2008).

Soil water content with depth was assessed with a soil moisture probe (PR2/6, Delta T, Cambridge UK) that was inserted into a plastic access tube placed to a depth of $1 \mathrm{~m}$. Access tubes were located inside but near the canopy edge of each species (one per species). An additional access tube was placed in a bare open surface location. Soil volumetric water content was estimated at depths of 10,20,30,40,60 and $100 \mathrm{~cm}$ to assess shifts in soil water extraction and response to precipitation recharge. Measurements were taken twice per month during the growing season period. Soil water in storage was calculated by weighting the depth increment with the volumetric soil water contents.

Precipitation was assessed with a tipping bucket rain gage with no shield (TB04, Campbell Scientific, Logan UT) and reference evapotranspiration was estimated with the Penman Monteith equation (Jensen et al., 1990) based on sensors associated with a standard $2 \mathrm{~m}$ meteorological tower (Campbell Scientific, Logan UT) (Table 2). 
Table 2. Water balance components; Precipitation, Evapotranspiration (ET), ET-Precipitation, ET ref $_{\text {(reference }}$ evapotranspiration), along with climate variables; Maximum and Minimum Temperatures, all based on time of year (month)

\begin{tabular}{lllllll}
\hline Month & Precipitation $(\mathrm{cm})$ & ET $(\mathrm{cm})$ & ET-Precipitation $(\mathrm{cm})$ & ETref $(\mathrm{cm})$ & Max Temp $\left({ }^{\circ} \mathrm{C}\right)$ & Min Temp $\left({ }^{\circ} \mathrm{C}\right)$ \\
\hline April & 3.05 & 3.44 & 0.39 & 17.7 & 21.8 & -18.5 \\
May & 2.79 & 5.62 & 2.82 & 16.1 & 24.6 & -6.7 \\
June & 0.03 & 3.93 & 3.90 & 21.2 & 33.7 & -4.9 \\
July & 2.62 & 4.71 & 2.09 & 23.0 & 36.4 & -0.2 \\
August & 0.43 & 3.05 & 2.62 & 21.3 & 33.6 & 0.0 \\
September & 0.00 & 1.88 & 1.88 & 17.7 & 32.1 & -5.1 \\
Totals & 8.92 & 22.63 & 13.71 & 117.0 & - & - \\
\hline
\end{tabular}

Chloride concentrations measured with depth (saturation extracts) were used to estimate the downward displacement of salts and also fractional water uptake (Equation 1) by the shrub species over the upper $150 \mathrm{~cm}$ of soil (Devitt, 1989). This approach provided an additional way of assessing where in the soil profile the four species were extracting water.

$$
\Sigma W j=\left(1-\left(\frac{C p}{C z}\right)\right) /(1-L F)
$$

(Equation 1)

$\mathrm{W}_{\mathrm{j}}$ represents the fractional water uptake for the surface to depth $\mathrm{z}$ region, and $\mathrm{Cp}$ and $\mathrm{C}_{\mathrm{z}}$ are the $\mathrm{Cl}^{-}$concentrations in the precipitation and in the soil solution at depth $\mathrm{z}$, respectively. We assumed a minimum leaching fraction ( $\mathrm{LF}=$ drainage volume/precipitation volume) of 0.01 based on the elevated chloride concentrations at the $150 \mathrm{~cm}$ depth. Chloride concentrations in precipitation were acquired from the National Atmospheric Deposition Program which we also assumed were constant over time. We also assumed a two-fold dilution to bring saturation extract water contents back to field soil moisture contents. A linear relationship in chloride concentration with depth (demonstrating a quasi-steady state condition) is needed to use the equation. Such a linear relationship was found under all four shrub species $(\mathrm{p}<0.001)$.

Plant water status was assessed by measuring leaf xylem water potentials (pressure bomb, PMS Instruments, Albany, OR) at mid-day to assess shifts in plant water potentials as upper vadose zone soil moisture declined. Midday leaf xylem water potential was measured from April to September, which represented the major growing period for all four species. Growth and overall health of plant canopies were assessed by monitoring canopy NDVI (Normalized Difference Vegetation Index, Devitt et al., 2010) with sensors (NDVI sensor, Skye Instruments, Llandrindod Wells, UK). NDVI values were used to assess shifts in phenology and the response of plants to summer precipitation events The sensors were mounted directly above the canopy of each selected shrub (height adjusted based on canopy projected area). Daily hourly values averaged between 1100 and 1400 hours are reported.

Data were analyzed using descriptive statistics, linear regression and Analysis of Variance. All statistical analyses were performed using SigmaStat Software (Systat Software Inc., Point Richmond, CA, USA).

\section{Results}

\subsection{Depth to Groundwater}

Groundwater depth at the site varied in a sinusoidal fashion over time with the shallowest depth occurring in mid-June (-5.5 m below land surface) and the deepest depth occurring in mid- October (-6.0 m). During the late fall to early summer period, groundwater levels rose in a linear fashion $\left(R^{2}=0.996, p<0.001\right)$, indicating that recharge was greater than discharge and redistribution whereas during the summer to early fall period groundwater levels declined in a linear fashion $\left(\mathrm{R}^{2}=0.995, \mathrm{p}<0.001\right)$, indicating that recharge was less than discharge and redistribution. This declining period was associated with groundwater pumping for the irrigation of alfalfa but it also overlapped with the active growing period of the phreatophyte greasewood, which entered into its annual senescence period in mid-October associated with the groundwater low point and subsequent rise in the groundwater level (reinforcement of the groundwater response signal).

\subsection{Soil Salinity}

Toward the end of the monitoring period (July and August) soil samples were taken adjacent to each species in the study. Samples were taken to a depth of at least $220 \mathrm{~cm}$ and in the case of greasewood to a depth of $340 \mathrm{~cm}$ (Figure 1). Soil salinity, as measured in saturation extracts $\left(E_{e}\right)$, increased in a linear fashion with depth $(0-150 \mathrm{~cm})$ when 
all samples were combined $\left(\mathrm{R}^{2}=0.78, \mathrm{p}<0.001\right)$. Peak salinity levels, in the $25-32 \mathrm{dSm}^{-1}$ range, occurred in the 140 $-180 \mathrm{~cm}$ depth before declining beyond that region. However at shallow depths $(0-40 \mathrm{~cm})$, soil salinity levels were below $4 \mathrm{dSm}^{-1}$, a level used to classify soils as saline (USSL, 1954). This range in salinity enabled halophytes (greasewood and shadscale) to live adjacent to non-halophytes (big sage and rabbitbrush). Chloride concentrations in the saturation extracts revealed similar patterns to salinity with chloride concentrations increasing in a linear fashion with depth $\left(\mathrm{R}^{2}=0.60, \mathrm{p}<0.001\right)$. Concentrations as high as $150-200 \mathrm{meq}^{-1}$ in the saturation extract occurred. In the case of rabbitbrush, the linear relationship between increasing chloride concentration with depth had a coefficient of determination of $0.91(\mathrm{p}<0.001)$ indicating a long term steady state water extraction pattern existed at this site (Devitt et al., 1989). Fractional water uptake estimates based solely on the chloride concentration profiles in the near surface region $(0-150 \mathrm{~cm})$ suggested that the majority of water uptake for all species occurred in the upper $30 \mathrm{~cm}(>90 \%$, note however that this approach only considered water extraction in the $0-150 \mathrm{~cm}$ zone).

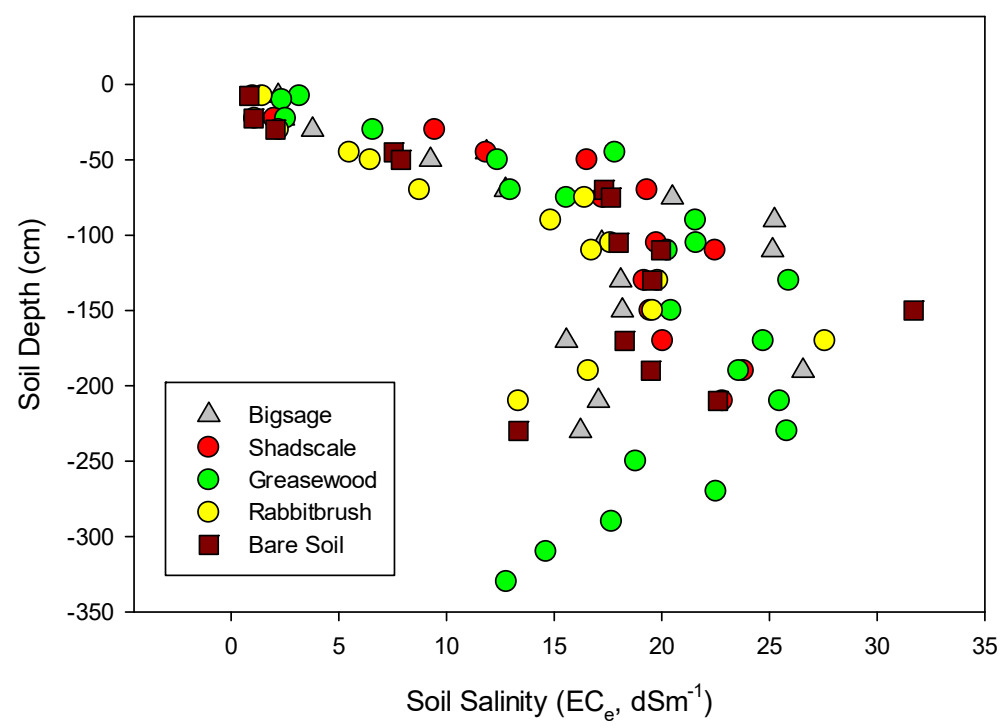

Figure 1. Soil salinity (ECe, saturation extract) measured with depth. Samples combined for all species

\subsection{Soil Water}

Soil water content estimated with depth was used to assess shifts in soil water in storage over time as an integral component of the hydrologic balance for the plant community. Changes in soil water content varied with each species and as temperature and environmental demand increased toward summer (Figure 2). Shadscale revealed the clearest sequential dry down in the upper $30 \mathrm{~cm}$ followed by greasewood and sagebrush to $40 \mathrm{~cm}$ and rabbitbrush to a depth beyond $40 \mathrm{~cm}$. It should be noted that a bare soil site revealed a similar soil water content pattern (data not shown) as observed with sites with plants, suggesting possible encroachment of roots from surrounding vegetation leading to a similar water extraction pattern. Although we can't state with certainty that the change in soil water content was not influenced by adjacent plants, the access tubes were placed underneath the canopy of the monitored shrub and care was taken to select shrubs that were in areas of the same species.

Soil water in storage is shown for two zonal depths in Figure 3 revealing a decreasing trend over time for all species in the $0-15 \mathrm{~cm}$ zone (similar in the $15-25$ and $25-35 \mathrm{~cm}$ zones, not shown). However in the $50-80 \mathrm{~cm}$ zone soil water in storage increased until mid-June indicating downward redistribution of soil water from the upper zones. There was a clear separation in the soil water in storage in the $50-80 \mathrm{~cm}$ zone with rabbitbrush having a 2-4 $\mathrm{cm}$ lower water in storage than found with the other 3 species. These continuously lower storage values under rabbitbrush suggested that water extraction was greater than the downward redistribution of soil water from the $35-50 \mathrm{~cm}$ zone into the $50-80 \mathrm{~cm}$ zone. Whereas at the deepest zone $(80-120 \mathrm{~cm}$, data not shown) shadscale had consistently higher storage values than under the other 3 species, suggesting greater downward redistribution of soil water compared to water extraction. Volumetric soil water content at a depth of $300 \mathrm{~cm}$ from a companion study (Koonce, 2016 ) for the period of July through October, averaged $0.06+/-0.004$, suggesting little downward movement of water below the salt bulge at $150 \mathrm{~cm}$. 

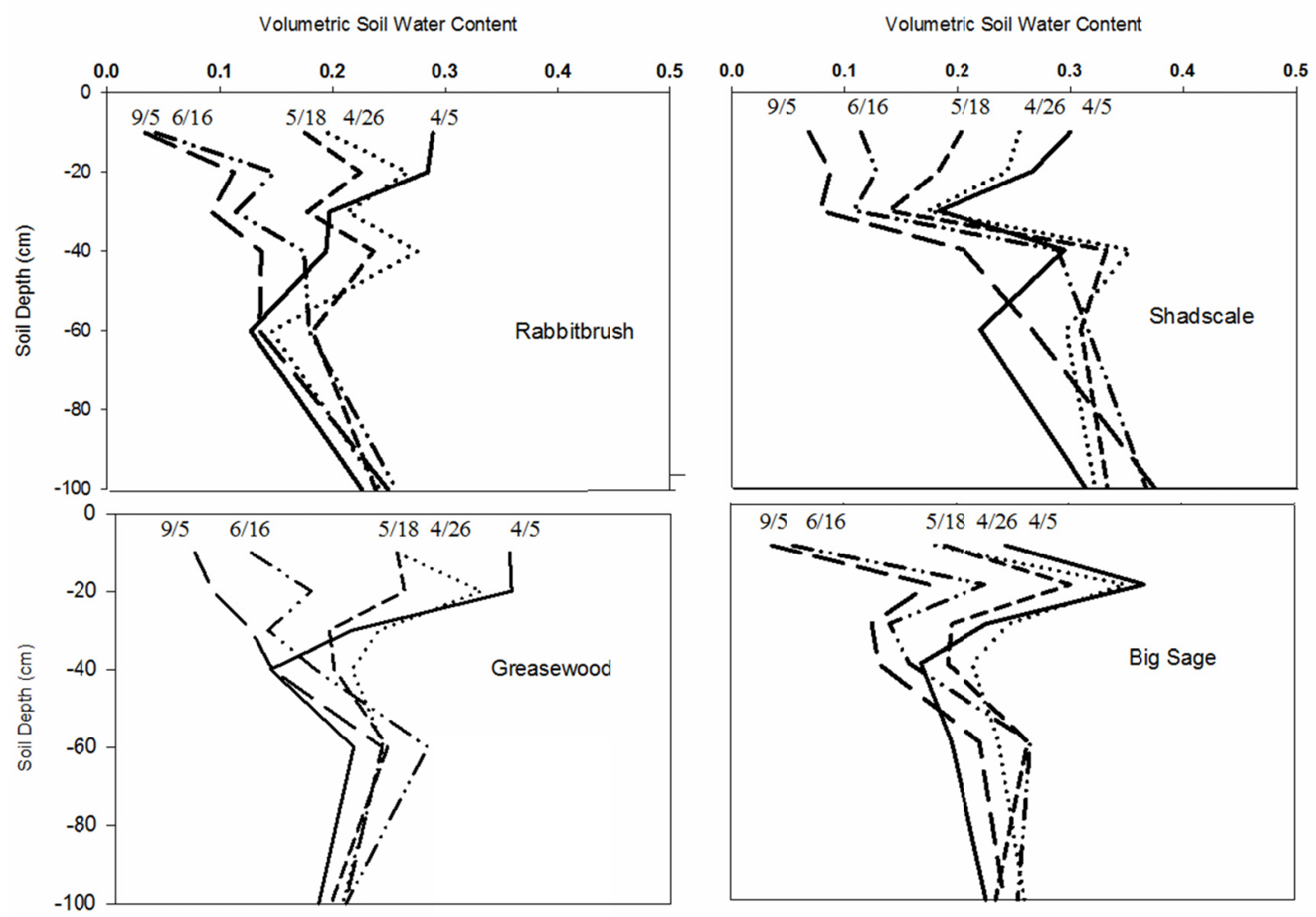

Figure 2. Soil volumetric water content estimated at 10, 20,30, 40, 60 and $100 \mathrm{~cm}$ soil depths for all four species over time. Numbers above each line represent the month/day

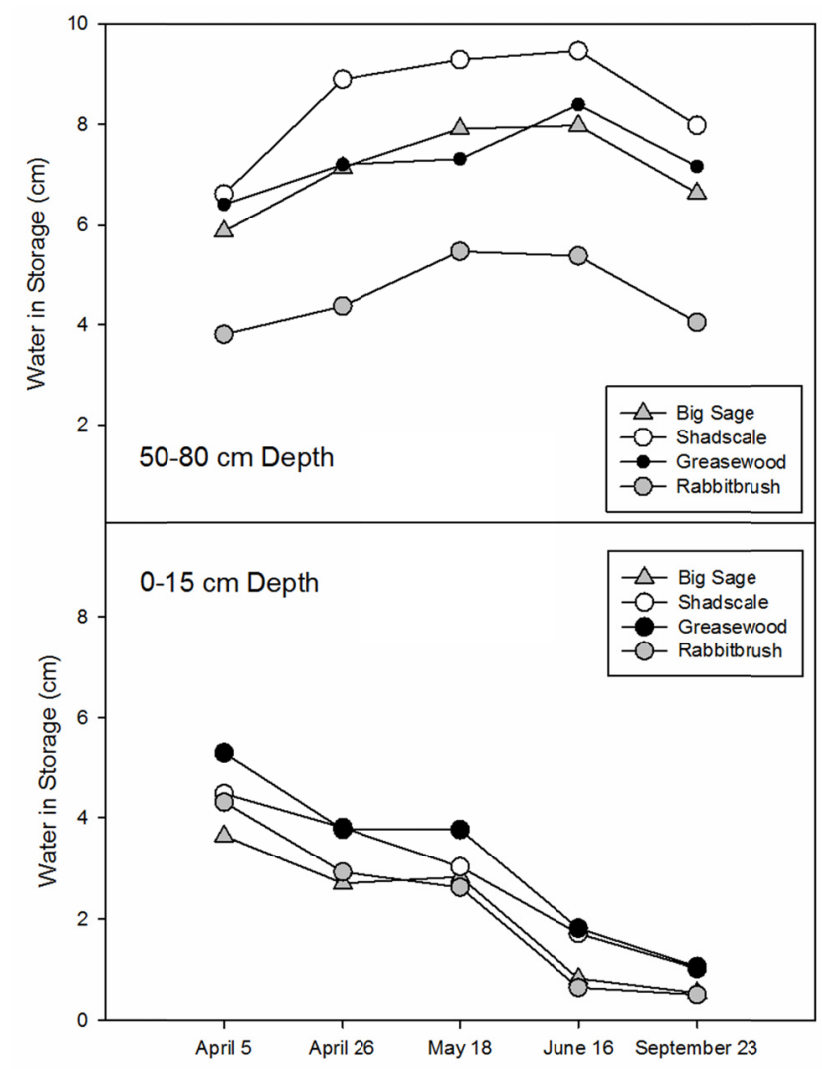

Figure 3. Soil water in storage $(\mathrm{cm})$ estimated in the $0-15 \mathrm{~cm}$ and $50-80 \mathrm{~cm}$ regions over time under all four species 


\subsection{Evapotranspiration}

Monthly ET totals are reported in Table 2, along with precipitation and reference ET (Penman-Monteith ET $\mathrm{T}_{\text {ref }}$ ). ET totals for the 6 month growing period totaled $22.63 \mathrm{~cm}$, which exceeded precipitation totals $(8.92 \mathrm{~cm})$ by $13.71 \mathrm{~cm}$, indicating water use also occurred from stored soil moisture at deeper depths within the vadose zone and/or from groundwater extraction by phreatophytes. $\mathrm{ET}_{\text {ref }}$ totaled $117.0 \mathrm{~cm}$, with the ratio of $\mathrm{ET}$ to $\mathrm{ET}_{\text {ref }}$ equaling 0.19 , reported not as a crop coefficient but merely as a site specific ratio depicting water use relative to environmental demand (under water limiting conditions).

\subsection{Plant Water Status}

Midday leaf xylem water potentials of all four species (Figure 4) were similar in mid-May. However, leaves of shadscale $(-4.86+/-0.35 \mathrm{MPa})$ and greasewood $(-4.80+/-0.30 \mathrm{MPa})$ declined below $-5 \mathrm{MPa}$ by the end of the summer (NS, $\mathrm{p}>0.05)$ while leaves of sagebrush declined after mid-June, stabilizing around $-4 \mathrm{MPa}(-3.83+/-$ $0.53)$, with four of the summer-fall dates significantly different from the other species $(\mathrm{p}<0.05)$. In contrast, rabbitbrush values did not decline after mid-June stabilizing around $-2.5 \mathrm{MPa}(-2.47+/-0.29)$, with all summer-fall potentials more positive than the other three species $(\mathrm{p}<0.05)$. Leaf xylem water potentials were plotted over time as a function of the summation of the product of \% storage depletion and $\mathrm{EC}_{\mathrm{e}}$ with depth (Figure 5), assuming the steady state salt distribution with depth measured at the end of the monitoring period were representative of conditions throughout the growing period (recognizing some change in the soil salinity profile could have occurred over the six-month period). As the soil water depletion weighted $\mathrm{EC}_{\mathrm{e}}$ increased, leaf xylem water potential declined in all species except Rabbitbrush. Sagebrush revealed a late summer response to precipitation as the \% storage depletion weighted $\mathrm{EC}_{\mathrm{e}}$ declined and leaf xylem water potential stabilized. However, rabbitbrush revealed no leaf xylem water potential response related to the increasing soil water depletion weighted $\mathrm{EC}_{\mathrm{e}}$ values over the upper $100 \mathrm{~cm}$ of soil, with September storage depletion $\mathrm{EC}_{\mathrm{e}}$ values very similar to greasewood. Such a response indicated that rabbitbrush was able to employ a different strategy to maintain higher and less variable leaf xylem water potentials throughout the entire growing period compared to the other species. We recognize that part of this leaf xylem water potential response may have been related to not only changing soil moisture availability but also to stomata control (which we did not measure, perhaps isohydric). However, we believe mid-day leaf xylem water potentials have value in terms of assessing maximum levels of plant water stress, especially under declining soil moisture availability and when all plants are grown under similar environmental conditions (reference ET, precipitation, soil type, slope, aspect and elevation).

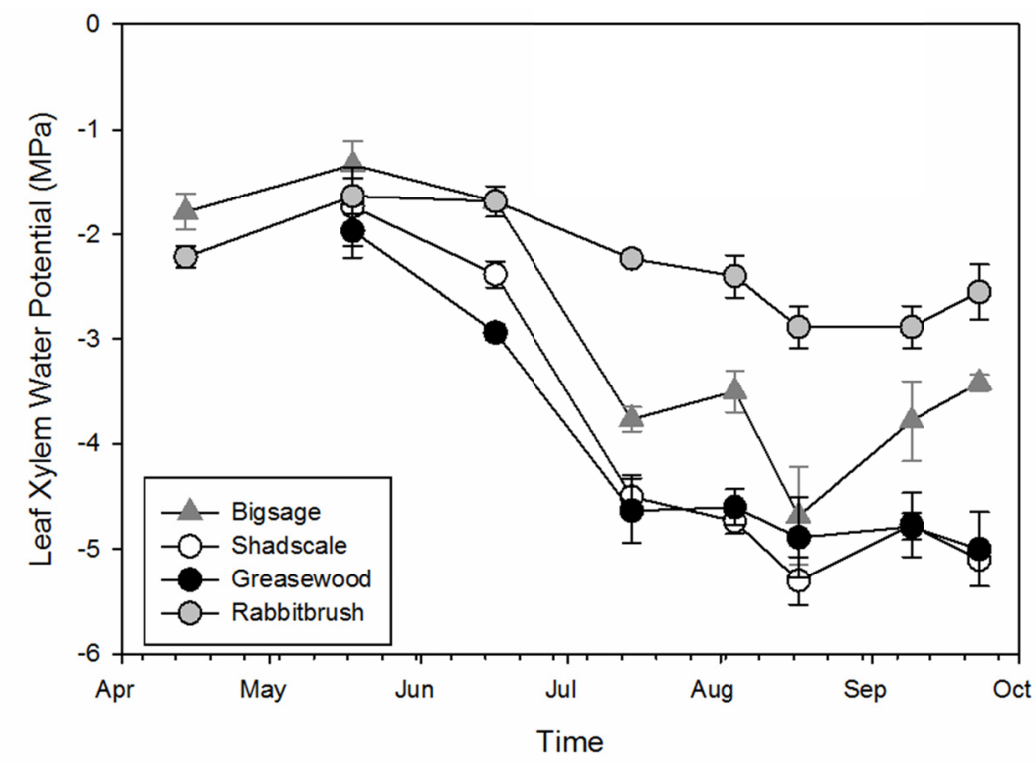

Figure 4. Mid-day leaf xylem water potentials (Mpa) with error bars for all four species assessed over the growing period 

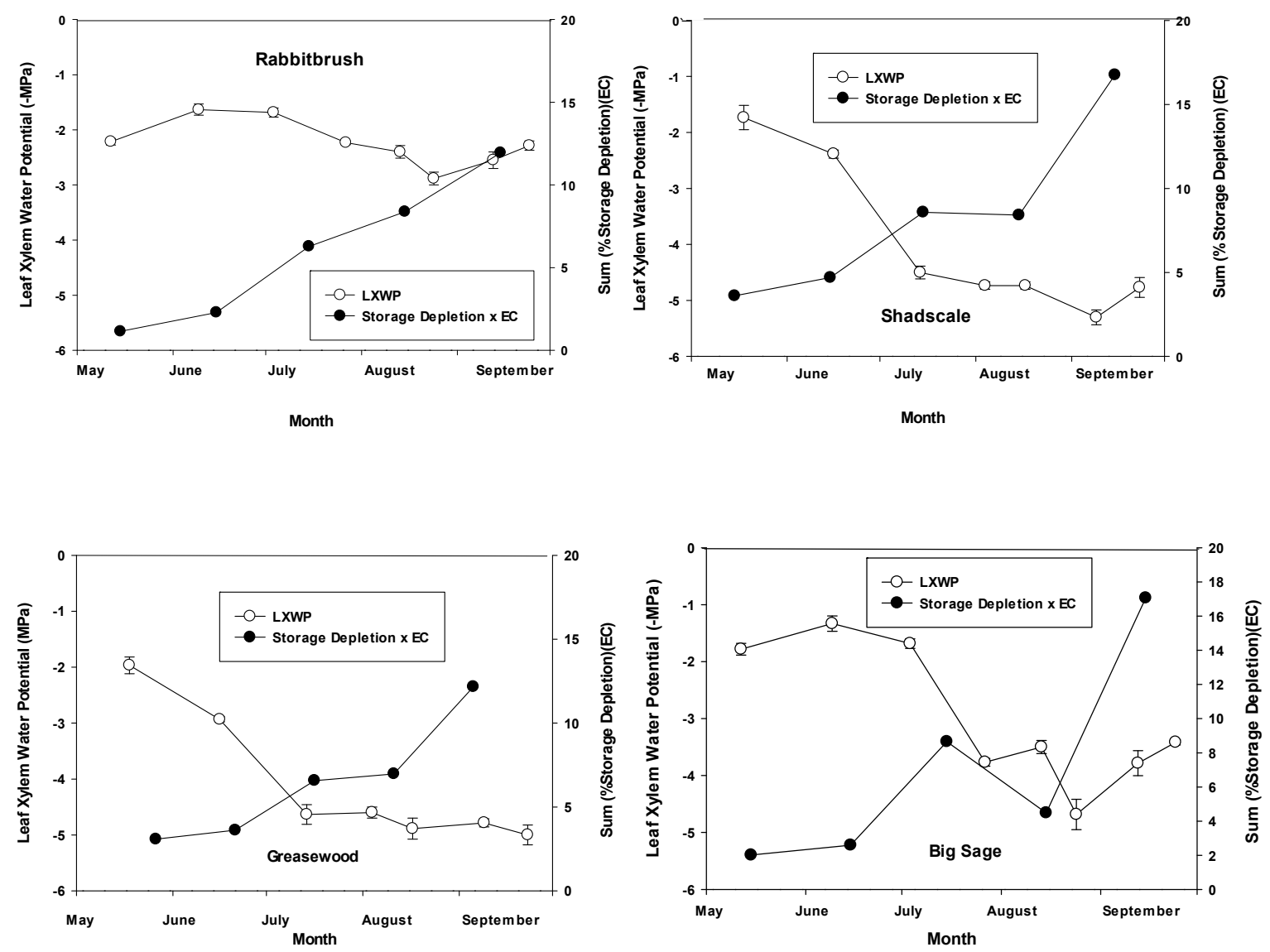

Figure 5. Mid-day leaf xylem water potentials (MPa) with error bars for all four species as a function of the summation of the product of \% storage depletion and ECe with depth $(0-100 \mathrm{~cm}$ zone)

\subsection{Ground Based NDVI}

To better assess the growth and physiological changes occurring over time with each species, average mid-day (1100-1400 hr) ground based NDVI values were obtained during the monitoring period (sensors positioned directly above the canopy). Due to installation delays and power failures, a full time series response (March-October) was only available for greasewood (Figure 6). NDVI during the dormancy phase of greasewood oscillated around 0.10 . However, NDVI rapidly increased as new leaf production occurred in response to warmer temperatures, rising to 0.57 by June 10. During the stable growth phase, there was a slight decline in NDVI showing the first signs of summer stress, with NDVI values declining from 0.57 to 0.44 between June 10 and July1. There was a data gap due to a power failure between July 5 and July 21, but data acquired from July 21 to July 31 revealed an increasing trend in NDVI from 0.51 to 0.59 in response to mid-summer precipitation that totaled 1.88 $\mathrm{cm}$ between July 26 and July 30. During late summer, greasewood NDVI values declined from 0.53 to 0.35 reducing further to 0.15 as greasewood entered into its period of senescence and winter dormancy.

Rabbitbrush and shadscale NDVI data remained fairly stable during the shorter monitoring period (late May-late September). Both species responded to warmer temperatures and precipitation during late spring with rabbitbrush NDVI increasing from 0.30 to 0.46 between May 11 and June 11, then declining again from June 11 to July 6 to 0.35 during an extended period of low precipitation and warmer temperatures. Shadscale revealed a similar response to the late May precipitation events with increasing NDVI values from 0.40 on May 28 to 0.58 on June 28, declining slightly later than rabbitbrush to 0.56 by July 6 . Both species revealed an increase in NDVI after late July (shadscale 0.65 , rabbitbrush 0.45 ) following three precipitation events $(0.37 \mathrm{~cm}$ on July $23,0.41 \mathrm{~cm}$ on August 7 and $0.42 \mathrm{~cm}$ on August 18). As precipitation ceased in the fall, both species began to show declines in NDVI values with shadscale reducing NDVI from 0.60 on August 30 to 0.53 on September 22, while rabbitbrush NDVI dropped from 0.42 on August 18 to 0.28 on September 23. Big sage showed a similar rise in NDVI as the other 
three species during the spring period rising from 0.14 in early April to 0.35 by late May. However, by mid-June NDVI values began to decline in a highly linear fashion from 0.25 to 0.10 by September $22\left(\mathrm{R}^{2}=0.85, \mathrm{p}<0.001\right)$.

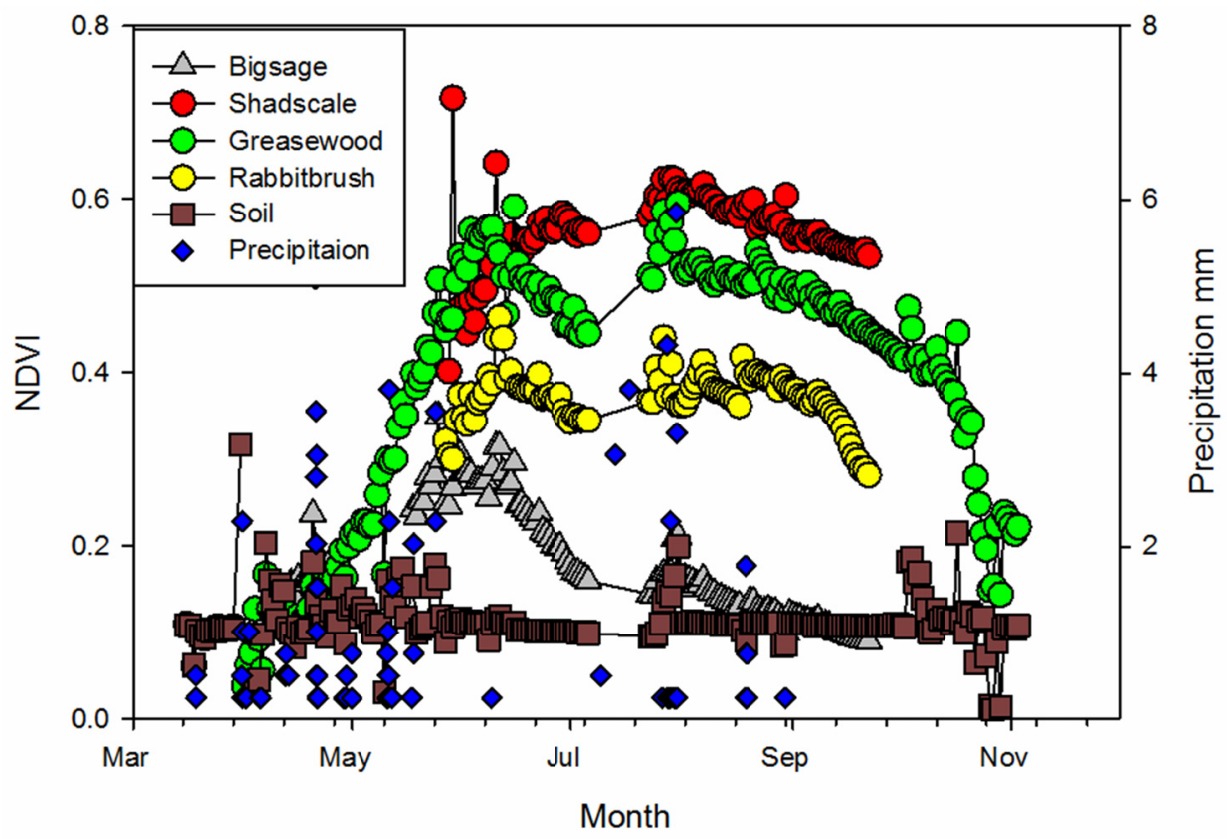

Figure 6. NDVI (Normalized Difference Vegetation Index) measured with sensors positioned directly above the canopies of all four speices over the growing period. Precipitation events $(\mathrm{mm})$ are indicated with blue circles

\subsection{Isotopic Analysis}

$\delta^{18} \mathrm{O}$ was analyzed in soil solution obtained from soil samples taken during the last 2 months of the monitoring period. $\delta^{18} \mathrm{O}$ in the soil solution revealed a highly linear decreasing relationship with depth over the upper $100 \mathrm{~cm}$ when all samples were combined $\left(\mathrm{R}^{2}=0.80, \mathrm{p}<0.001\right.$, Figure 7$)$. In the case of rabbitbrush, the coefficient of determination for this relationship was the highest at $0.93(\mathrm{p}<0.001)$. Below $100 \mathrm{~cm}, \delta^{18} \mathrm{O}$ values stabilized in the -20 to $-25 \%$ range. However, in an area that was void of vegetation $\left(>4 \mathrm{~m}^{2}\right.$ area $) \delta^{18} \mathrm{O}$ increased with depth over the upper $60 \mathrm{~cm}$, rising from $-23 \%$ o $(10 \mathrm{~cm})$ to $-14 \%$ o $(60 \mathrm{~cm})$, followed by a linear decreasing trend similar to what was observed in soil samples taken adjacent to plants (Figure 8, bare soil vs adjacent to rabbitbrush).

Only under greasewood were we able to sample beyond $220 \mathrm{~cm}$ with samples at $340 \mathrm{~cm}$ having $\delta^{18} \mathrm{O}$ values just below $-20 \%$. Groundwater samples taken during the monitoring period covering low and high groundwater levels revealed fairly stable $\delta^{18} \mathrm{O}$ values that ranged from - 16.6 to $-16.8 \%$, whereas precipitation varied from - $12 \%$ (May) to $-6.6 \%$ (July) to $-6.5 \%$ (August). The summer $\delta^{18} \mathrm{O}$ values in the precipitation were similar to values found in the near surface soil region associated with all four species.

$\delta^{18} \mathrm{O}$ in the plant was assessed by sampling woody twigs from the shrub canopies on a monthly basis during the study. Results reported in Figure 9 revealed that $\delta^{18} \mathrm{O}$ values in the xylem water became more negative with time. Only in the case of greasewood did the average $\delta^{18} \mathrm{O}$ values in the plant become more negative than in the groundwater. During May, values of $\delta^{18} \mathrm{O}$ in the xylem water of all the species except greasewood were at levels similar to precipitation $(-12 \%)$. However, in both greasewood and rabbitbrush, $\delta^{18} \mathrm{O}$ became more negative by June, whereas in shadscale and big sage, $\delta^{18} \mathrm{O}$ levels became more positive $(p<0.05$, species effect). By the end of the monitoring period, rabbitbrush, shadscale and big sage converged on an $\delta^{18} \mathrm{O}$ value of approximately $-15 \%$, slightly above that found in the groundwater, whereas in greasewood the $\delta^{18} \mathrm{O}$ value declined to -19\%o. In Figure $10, \delta^{18} \mathrm{O}$ in the soil moisture, groundwater, precipitation and in the xylem water are plotted over time, revealing species specific trends. . Unfortunately, the $\delta^{18} \mathrm{O}$ values at different depths in the soil for each species over lapped with $\delta^{18} \mathrm{O}$ values in the groundwater. In the case of rabbitbrush $\delta^{18} \mathrm{O}$ in the xylem water was relatively stable from May to October. $\delta^{18} \mathrm{O}$ values ranged between -13 and $-15 \%$ which was lower than precipitation but higher than groundwater. Soil $\delta^{18} \mathrm{O}$ values at 50 and $70 \mathrm{~cm}$ below rabbitbrush were in the -12 to $-14 \%$ range suggesting that 
rabbitbrush may have been accessing water from this region to a greater extent, although higher soil salinity may have restricted/reduced soil water extraction from this zone.

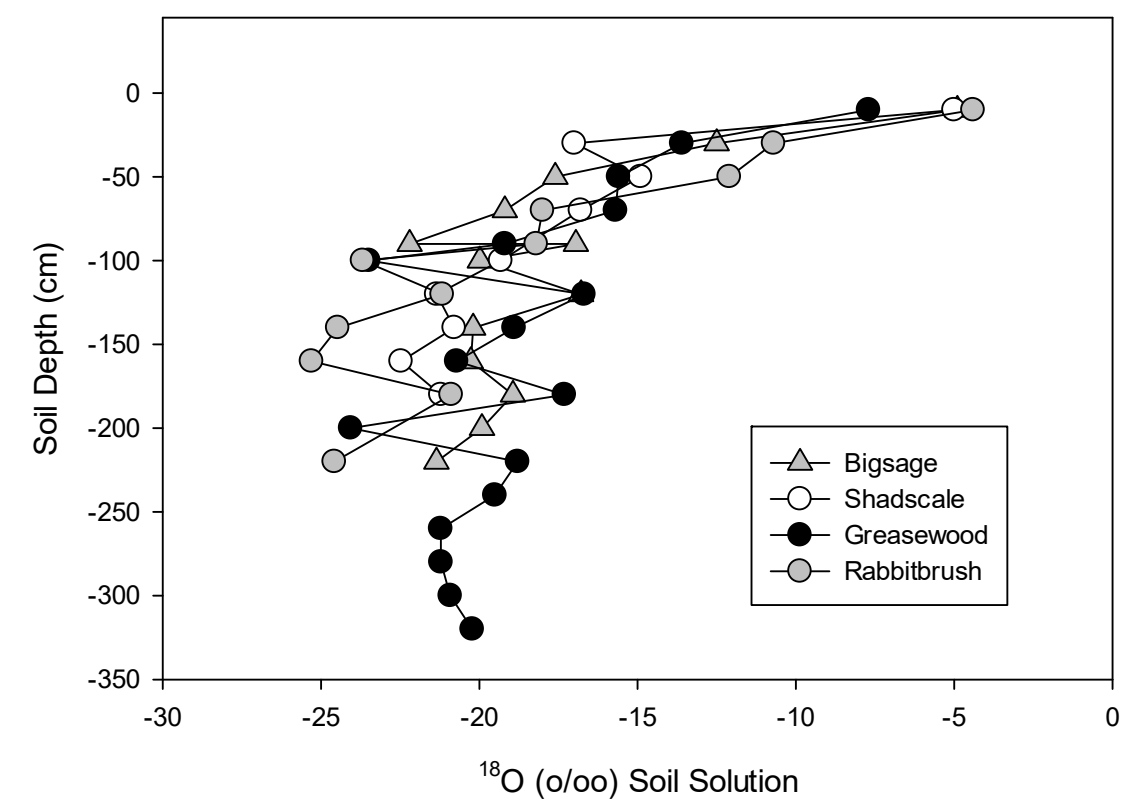

Figure 7. $\delta^{18} \mathrm{O}$ in the soil solution from different depths, data combined for all four species.

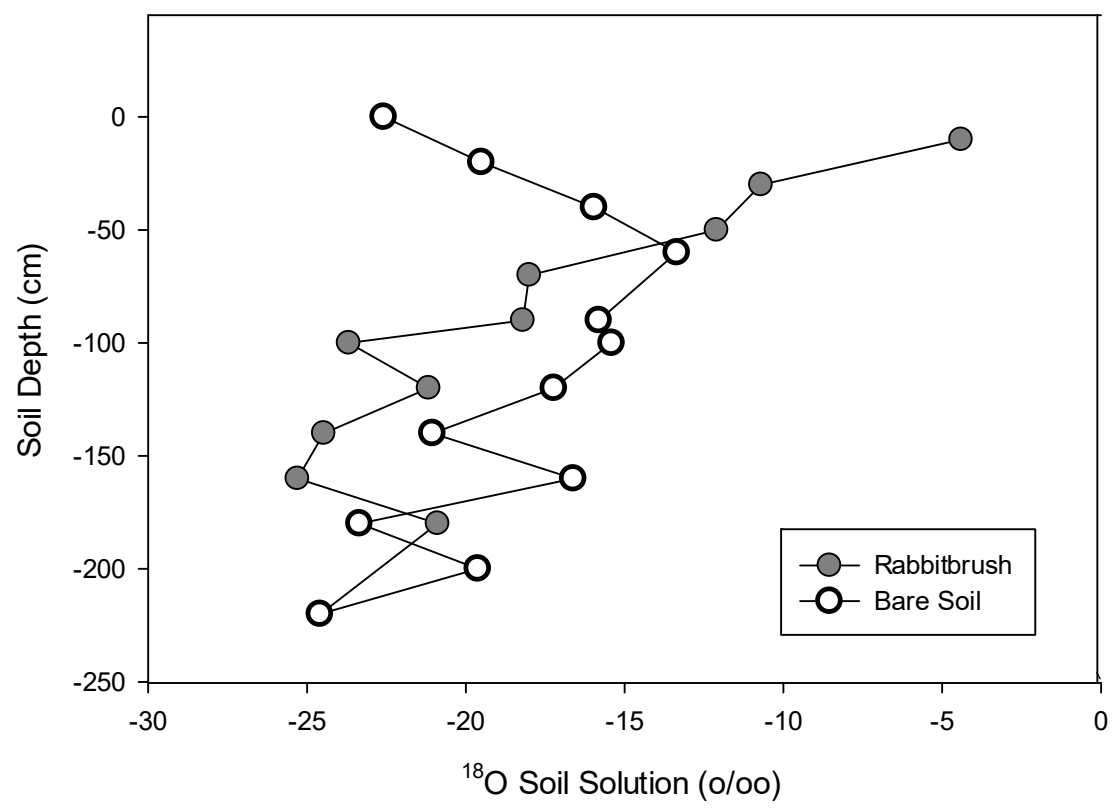

Figure $8 . \delta^{18} \mathrm{O}$ in the soil solution from different depths, contrasting values obtained under rabbitbrush vs. from an adjacent region with bare soil void of vegetation 


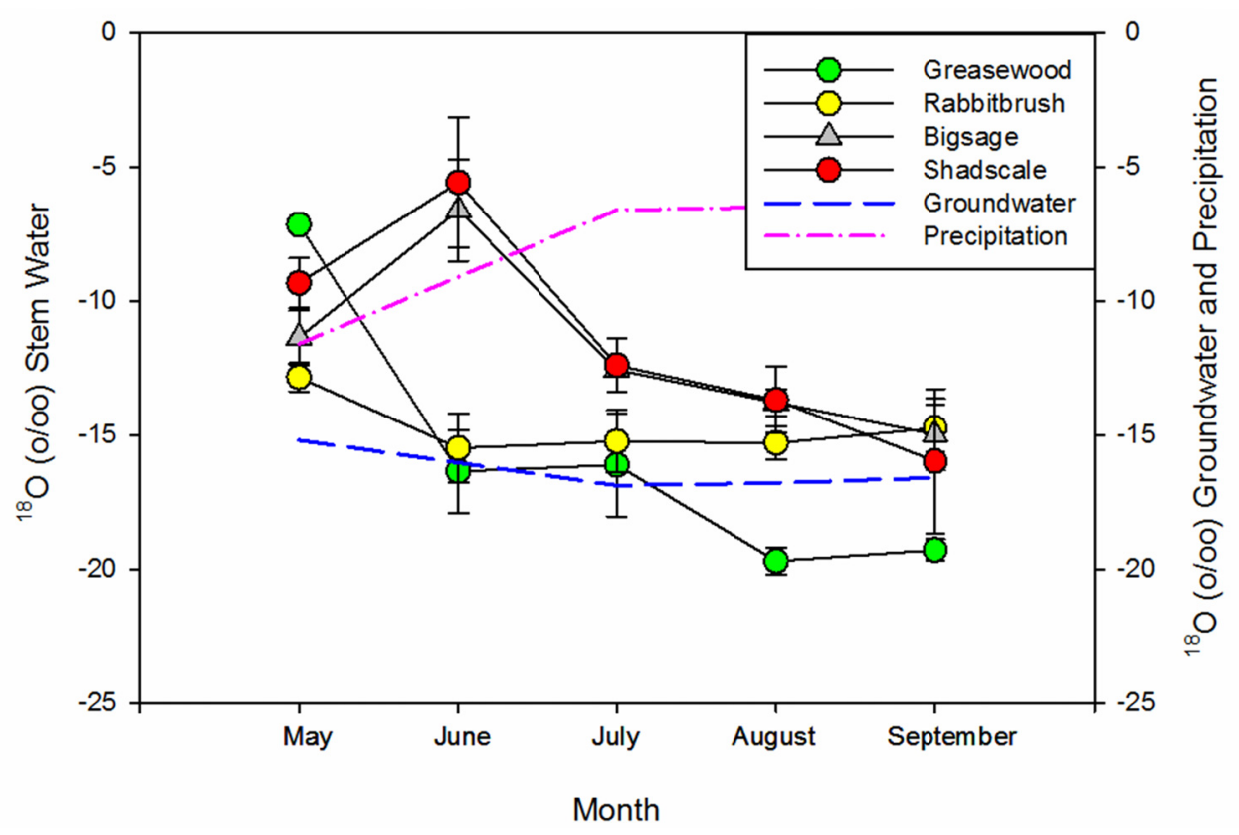

Figure $9 . \delta^{18} \mathrm{O}$ in the xylem water for all four species over time along with values for groundwater and precipitation
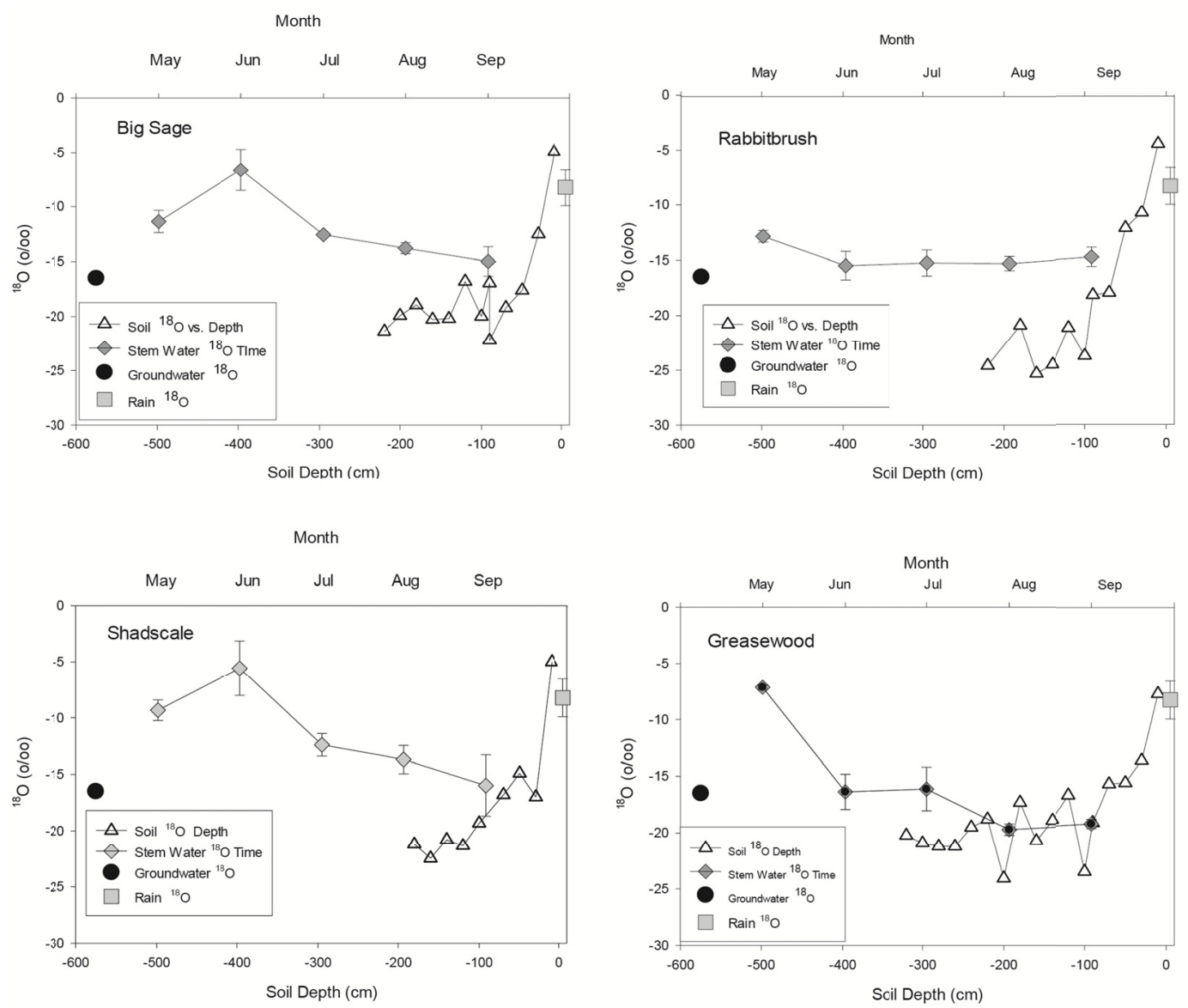

Figure 10. $\delta^{18} \mathrm{O}$ in soil solution, groundwater, precipitation and in the xylem water for all four species over time 
We utilized a mixing model (EPA, IsoSource) to assess which sources of water might be contributing to the $\delta^{18} \mathrm{O}$ signature in the plants. A vertical isotopic gradient is needed in the soil profile to differentiate soil water extraction patterns by plants (Donovan, 1998). This model requires identifying the potential sources and limiting these sources to sources with distinct signatures. The model predicts "feasible solutions", characterizing the entire distribution of these solutions (Phillips, 2005). We considered the following potential sources of water; precipitation, groundwater and soil water from the $0-10 \mathrm{~cm}, 30-70 \mathrm{~cm}$ and $90-180 \mathrm{~cm}$ depths. The user of the model must filter/select source components based on knowledge of the site. If all water sources were considered to be accessible by the plants the model predicted a groundwater component for all four species and a soil component from the 90-180 cm depth. However, based on depth to groundwater and elevated soil salinity we did not consider non- halophytes to have access to groundwater at this site. Instead we believe the model output inferring groundwater uptake was driven by the over lapping $\delta^{18} \mathrm{O}$ values in the soil water with that found in groundwater. In cases where we felt justified not including groundwater and the soil from the $90-180 \mathrm{~cm}$ depth that was highly salinized we also considered soil from a non-vegetated area at depths of 0-10 and 30-70 cm. Results from the mixing model using this approach are reported in Table 3. We only report the results for July and September, since all soil sampling for $\delta^{18} \mathrm{O}$ in the soil took place toward the end of the monitoring period, we used different values for precipitation, groundwater and the stem xylem water but we used the same soil solution values (realizing some differences may have occurred with depth over this two month period). We ran the mixing model (Table 3), accepting groundwater as a potential source only for greasewood, a known phreatophyte in the region (Devitt et al., 2010, Devitt \& Bird, 2015).

Based on the high standard deviations associated with the mean values (Table 3), it was not possible to make the case that the $\delta^{18} \mathrm{O}$ values could be used to distinguish significant differences in the water extraction patterns of sagebrush, shadscale and rabbitbrush. These three species revealed similar source component contributions when groundwater and the 90-180 cm depth source components were not considered. However, a clear distinction could be made when comparing the source components for greasewood, with $97 \%$ of the $\delta^{18} \mathrm{O}$ acquired by greasewood in September being associated with the $90-180 \mathrm{~cm}$ depth region. Greasewood revealed significant differences between the July and September source components. Output from the model revealed a decrease in the groundwater component for greasewood from $30 \%$ in July to $2 \%$ in September, with a major shift to the $90-180 \mathrm{~cm}$ source component (38\% in July to $97 \%$ in September). Only in the case of rabbitbrush were there no solutions generated if only $\delta^{18} \mathrm{O}$ values next to the plant were considered (and when no groundwater or soil moisture extraction from the deeper sources considered, Table 3). Solutions were only possible if $\delta^{18} \mathrm{O}$ values from the bare soil region were also considered. The highest contribution from a soil depth component in rabbitbrush occurred from the bare soil $0-10 \mathrm{~cm}$ region (July, 30\%+/-13). Rabbitbrush was also the only species to show a statistical difference $(\mathrm{p}<0.05)$ from the contribution in the $0-10 \mathrm{~cm}$ region from a bare soil area vs adjacent to the plant (July, $10 \%+/-8)$.

Table 3. Water uptake estimates (\%, IsoSource program) reported as mean $+/$ - standard deviation for all 4 species for the months of July and September. Sources of water differed for the species. 0-10 cm plant, 30-70 cm plant and 90-180 cm plant refers to soil samples taken adjacent to plants vs. $0-10 \mathrm{~cm}$ bare soil and $30-70 \mathrm{~cm}$ bare soil refers to soil samples taken from an area void of vegetation

\begin{tabular}{|c|c|c|c|c|c|}
\hline & \multicolumn{3}{|c|}{ Greasewood } & \multicolumn{2}{|c|}{ Rabbitbrush } \\
\hline & July & Sept & & July & Sept \\
\hline Precipitation & $6+/-5$ & 0 & Precipitation & $12+/-9$ & $13+/-10$ \\
\hline Groundwater & $30+/-22$ & $2+/-2$ & $0-10 \mathrm{~cm}$ bare soil & $30+/-13$ & $26+/-13$ \\
\hline $0-10 \mathrm{~cm}$ plant & $7+/-6$ & 0 & $30-70 \mathrm{~cm}$ bare soil & $28+/-21$ & $28+/-20$ \\
\hline $30-70 \mathrm{~cm}$ plant & $19+/-15$ & $1+/-1$ & $0-10 \mathrm{~cm}$ plant & $10+/-8$ & $11+/-9$ \\
\hline \multirow[t]{3}{*}{$90-180 \mathrm{~cm}$ plant } & $38+/-17$ & $97+/-1$ & $30-70 \mathrm{~cm}$ plant & $21+/-16$ & $23+/-18$ \\
\hline & \multicolumn{3}{|l|}{ Big Sage } & \multicolumn{2}{|c|}{ Shadscale } \\
\hline & July & Sept & & July & Sept \\
\hline Precipitation & $23+/-14$ & $14+/-10$ & Precipitation & $23+/-15$ & $10+/-8$ \\
\hline $0-10 \mathrm{~cm}$ bare soil & $15+/-10$ & $22+/-14$ & $0-10 \mathrm{~cm}$ bare soil & $14+/-10$ & $28+/-15$ \\
\hline $30-70 \mathrm{~cm}$ bare soil & $21+/-15$ & $26+/-20$ & $30-70 \mathrm{~cm}$ bare soil & $20+/-15$ & $26+/-20$ \\
\hline $0-10 \mathrm{~cm}$ plant & $22+/-13$ & $12+/-9$ & $0-10 \mathrm{~cm}$ plant & $22+/-13$ & $9+/-8$ \\
\hline $30-70 \mathrm{~cm}$ plant & $20+/-15$ & $26+/-20$ & $30-70 \mathrm{~cm}$ plant & $20+/-15$ & $26+/-20$ \\
\hline
\end{tabular}




\section{Discussion}

Shrublands throughout the western United States face an uncertain future not only because of possible climate warming (Dominguez et al., 2012, Hurteau et al., 2014) but also because of potential groundwater pumping (Toft, Devitt et al., 2010). Such driving forces may alter plant community dynamics favoring one species over another. Warming temperatures and lower precipitation and/or more variable precipitation could lead to increased competition for available soil moisture. Such a situation could lead to soil salinity levels rising to the point that non halophytes would become displaced by halophytes. At the Spring Valley site monitored in this study, the groundwater depth oscillated between approximately 5.5 and $6.0 \mathrm{~m}$ below the ground surface with a salt buildup at $1.5 \mathrm{~m}$ that would have restricted growth of any non-halophyte species (Gorham 1995). Based on previous analysis (Conrad, 2008) of plant tissue from the four major shrub species in the experimental area, both big sage and rabbitbrush (non-halophytes) were not accumulating specific ions $(\mathrm{Na}$ and $\mathrm{Cl}$ ) in leaf tissue, whereas shadscale and greasewood (halophytes) had elevated ionic concentrations, with Na as high as $9 \%$.

The halophytes and non-halophytes grew in close association with each other within the mixed shrubland plant community. Extraction of water within the upper $100 \mathrm{~cm}$ was evident for all four species during the growing period indicating that the halophytes were not obligate halophytes requiring fully salinized soil profiles and that all four species competed for soil moisture recharged from precipitation events. Rabbitbrush responded quite differently from the other species by maintaining average midday leaf xylem water potentials that never dropped below -2.88 MPa even during the middle of summer. Hacke (2000) reported that control of midday leaf water potential is critical for rabbitbrush because embolisms increase sharply between -2 and -4 MPa. Although rabbitbrush was reported by Lin and Ehleringer (1996) to show little if any uptake of summer rains, continuous NDVI values recorded over rabbitbrush at our site suggested multiple responses to summer precipitation events. Donovan and Richards (1996) reported rabbitbrush and greasewood to be somewhat non responsive to moisture in surface soil layers because they were acting as phreatophytes. At our site we found that soil moisture depletion was occurring in the upper $100 \mathrm{~cm}$, with greater depletion under rabbitbrush, yet midday leaf xylem water potentials were independent of the summation of the EC weighted soil moisture depletion, suggesting that greater water extraction occurred at depths that might need to be given greater radial weighting (perhaps greater stomata control as well). Although greasewood was accessing both groundwater and near surface soil water in July based on the mixing model, midday leaf xylem water potential still fell to below -5.5 MPa. This suggests a direct osmotic adjustment that may have enabled access to soil water from regions with salinity in excess of seawater (perhaps anisohydric). James et al. (2006) reported on $\mathrm{Na}$ and $\mathrm{K}$ regulation in the leaf apoplast of desert shrubs where high concentrations of osmotica were used to maintain leaf pressure potentials and stomata conductance.

Groundwater extraction was predicted for greasewood during the July period but little for the September period indicating that greasewood was not an obligate phreatophyte at this site. Similar results were found by Devitt and Bird (2015) in Snake valley Nevada. Based on the $\delta^{18} \mathrm{O}$ data, greasewood relied on water extraction from the deeper vadose zone where salt buildup would have restricted access by big sage and rabbitbrush, providing an additional advantage to greasewood. Greasewood demonstrated plasticity in accessing different water sources over time. Eggemeyer et al. (2009) reported on plasticity in sources of water uptake for pine and juniper trees but also reported on overlapping isotopic values found in soils resulted in poorer model predictions, which also placed some limitations on our analysis as well. If groundwater levels decline this would no doubt have an impact on greasewood's ability to maintain favorable water relations and grow, but it may not mean that the species would be displaced as $\delta^{18} \mathrm{O}$ values indicated that greasewood was accessing water in the deeper vadose zone not accessed by the non-halophytes. Accessing soil water high in salts in different parts of the soil profile that non halophytes did not access allowed for greater coexistence of the species. In a previous study (Devitt and Bird, 2015) in the Great Basin it was documented that greasewood continued to access groundwater at depths below $10 \mathrm{~m}$ but no information is available on the maximum rooting depth of this species.

The isotopic mixing model predicted a similar water extraction pattern for shadscale, big sage and rabbitbrush that contrasted with greasewood which had a groundwater component. We asked the question whether rabbitbrush could have also accessed groundwater at the site which would have provided a more reliable source of high quality water ( $500 \mathrm{mg} / \mathrm{l}$, TDS). Donovan et al. (1996) suggested that rabbitbrush may have reached groundwater at depths of $3.4-5 \mathrm{~m}$ in California where soil salinity levels were around $1.5 \mathrm{dSm}^{-1}$ in saturation extracts (sandy soil). We believe rabbitbrush would have been restricted from reaching groundwater at depths of 5.5-6 m at our site because of soil salinity (ECe) in the $25-32 \mathrm{dSm}^{-1}$ range. We also believe if rabbitbrush was capable of growing through the high saline region with $\delta^{18} \mathrm{O}$ values $<-19 \%$ the isotopic signature in the xylem water should have reflected this, with values more similar to greasewood, which did not occur. 
The fact that rabbitbrush only represented $1.6 \%$ of the cover suggested either rabbitbrush was a recent entry to the plant community or strong competition was limiting its presence. We do not believe rabbitbrush was a recent entry (established plant community with no apparent disturbances) because it had a well-developed steady state chloride profile in the soil that represented a long term water extraction pattern; instead we believe it was limited at this site because it lacked groundwater access for a competitive advantage. Nichols (1994) reported that rabbitbrush and big sage were found to coexist in the Great Basin where soils and groundwater were less saline. Because of the high salinity levels rabbitbrush may be undergoing displacement at this site. We believe the data suggests that rabbitbrush was more efficient in accessing lower salinity water in the upper $50 \mathrm{~cm}$. The fact that rabbitbrush was able to maintain tight control of midday leaf xylem water potentials suggests it may have had access to a very stable source of water, similar to the findings of Sperry and Hacke (2002). Fractional water uptake based on steady state chloride profiles suggested that $>90 \%$ of the water uptake would have taken place in the upper $30 \mathrm{~cm}$. Lower soil water in storage in the $50-80 \mathrm{~cm}$ region also supported greater water extraction in the upper region by rabbitbrush. However the $35-50 \mathrm{~cm}$ zone did not have a $\delta^{18} \mathrm{O}$ signature that would have allowed acceptable closure with the $\delta^{18} \mathrm{O}$ in the xylem water. The mixing model indicated that when we considered a water component from areas classified as bare soil (no vegetative cover) that possessed more negative $\delta^{18} \mathrm{O}$ levels, the model predicted a $30 \%+/-13 \%$ source component for rabbitbrush in the $0-10 \mathrm{~cm}$ depth in July compared to only $10 \%+/-8 \%$ for this same depth adjacent to the plant $(\mathrm{p}<0.05)$.

Although we cannot state with complete certainty that rabbitbrush was accessing more soil water from open areas than other species, it does suggest a complex water extraction pattern in mixed open shrub plant communities, and it also suggests that greater sampling is necessary, as one should not assume the water available next to a plant is the same at some distance away from the plant (true for all species). A limitation to our study was that the rooting depth and radial distribution patterns were not assessed for the four species. Although we assessed changes in soil water, this was done at one set point relative to the plants. If the plants were able to access water at greater radial distances, the available soil water in storage would have been much greater allowing for greater buffering during periods of higher environmental demand. Rabbitbrush at our site may have employed a different rooting strategy and soil water extraction pattern in the upper $1 \mathrm{~m}$ to access water that the other species were not accessing to the same extent, allowing for maintenance of more positive mid-day leaf xylem water potentials (recognizing stomata control may have also played a significant role). However, Pataki et al. (2008) suggested that care must be taken in inferring root distributions based on $\delta^{18} \mathrm{O}$ values, that such values should be viewed only as supportive evidence of rooting depth.

\section{Summary and Conclusions}

Taken together, results from our study indicate (i) all four species competed for soil moisture recharged by precipitation as evidenced from dry-down in the upper $m$ of the soil profile and by subtle shifts in the measured NDVI at the canopy level associated with rainfall events. As soil moisture declined, leaf xylem water potential also declined but rabbitbrush was able to maintain significantly higher more positive values than the other species, recognizing that stomata regulation could also have influenced this response, (ii) $\delta^{18} \mathrm{O}$ in the soil became more negative with depth as did plant xylem water $\delta^{18} \mathrm{O}$ values over time. Results from the mixing model were complicated by the over-lapping values for groundwater and soil values found at deeper depths. However with greasewood, $\delta^{18} \mathrm{O}$ values in the xylem water indicated water extraction from the deeper vadose zone where salt buildup would have restricted access by big sage and rabbitbrush. It appeared that only greasewood was accessing groundwater at our site and that phenotypic plasticity allowed this species to also shift utilization to deeper saline vadose zone water. Further, the balances between halophytes and non-halophytes, and between phreatophytes and non-phreatophytes, appear to depend on (i) precipitation maintaining non-saline conditions in the near surface horizon, (ii) development of a well- defined salt bulge at the $150 \mathrm{~cm}$ depth, and (iii) the occurrence of groundwater at $6 \mathrm{~m}$, all of which enabled the coexistence of the four shrub species through "phyto-hydrologic" niche separation (Lin and Ehleringer (1996), Leffler et al. (2004) and Eggmeyer etal. (2009). All of these plant-soil water relationships can be altered by climate change and groundwater pumping which may profoundly affect the structure and function of these ubiquitous Great Basin shrubland ecosystems.

\section{Acknowledgements}

The information reported in this manuscript is based upon work supported by the US national Science Foundation under grants EPS-0814372 and EPS-0919123.

\section{References}

Barnett, T. P., \& Pierce, D. W. (2008). When will Lake Mead go dry? Water Resour. Res., 44, W03201. https://doi.org/10.1029/2007WR006704. 
Busch, D. E., Ingraham, N. L., \& Smith, S. D. (1992). Water uptake in woody riparian phreatophytes of the southwestern United States: a stable isotope study. Ecological Applications, 2(4), 450-459.

Chimner, R. A., \& Cooper, D. J. (2004). Using stable oxygen isotopes to quantify the water source used for transpiration by native shrubs in the San Luis Valley, Colorado USA. Plant and Soil, 260(1-2), 225-236.

Christensen, N. S., Wood, A. W., Voisin, N., Lettenmaier, D. P., \& Palmer, R. N. (2004). The effects of climate change on the hydrology and water resources of the Colorado River basin. Climatic change, 62(1-3), 337-363.

Conrad, B. (2008). Investigation of plant water use in the Great Basin. NV.UNLV Theses. Paper 991.

Devitt, D. A. (1989). Bermudagrass response to leaching fractions, irrigation salinity, and soil types. Agronomy journal, 81(6), 893-901. https://doi.org/10.2134/agronj1989.00021962008100060010x

Devitt, D. A., \& Bird, B. (2016). Changes in groundwater oscillations, soil water content and evapotranspiration as the water table declined in an area with deep rooted phreatophytes. Ecohydrology, 9(6), 1082-1093.

Devitt, D. A., Fenstermaker, L. F., Young, M. H., Conrad, B., Baghzouz, M., \& Bird, B. M. (2011). Evapotranspiration of mixed shrub communities in phreatophytic zones of the Great Basin region of Nevada (USA). Ecohydrology, 4(6), 807-822. https://doi.org/10.1002/eco.169. 60

Dominguez, F., Rivera, E., Lettenmaier, D. P., \& Castro, C. L. (2012). Changes in winter precipitation extremes for the western United States under a warmer climate as simulated by regional climate models. Geophysical Research Letters, 39(5). https://doi.org/1029/2011GL05762

Donovan, L. A., Richards, J. H., \& Muller, M. W. (1996). Water relations and leaf chemistry of Chrysothamnus nauseosus ssp. consimilis (Asteraceae) and Sarcobatus vermiculatus (Chenopodiaceae). American Journal of Botany, 83(12), 1637-1646.

Donovan, L. A., Richards, J. H., \& Schaber, E. J. (1997). Nutrient relations of the halophytic shrub, Sarcobatus vermiculatus, along a soil salinity gradient. Plant and Soil, 190(1), 105-117.

Eggemeyer, K. D., Awada, T., Harvey, F. E., Wedin, D. A., Zhou, X., \& Zanner, C. W. (2009). Seasonal changes in depth of water uptake for encroaching trees Juniperus virginiana and Pinus ponderosa and two dominant C4 grasses in a semiarid grassland. Tree physiology, 29(2), 157-169. https://doi.org/10.1093/treephys/tpn019

Eggemeyer, K. D., Awada, T., Harvey, F. E., Wedin, D. A., Zhou, X., \& Zanner, C. W. (2009). Seasonal changes in depth of water uptake for encroaching trees Juniperus virginiana and Pinus ponderosa and two dominant C4 grasses in a semiarid grassland. Tree physiology, 29(2), 157-169.

Gorham, J. (1995). Mechanism of salt tolerance of halophytes. Halophytes and biosaline agriculture, 31.

Harrill, J. R., Welch, A. H., Prudic, D. E., Thomas, J. M., Carman, R. L., Plume, R. W., ... \& Mason, J. L. (1983). Aquifer systems in the Great Basin region of Nevada, Utah, and adjacent states: A study plan (No. 82-445). US Geological Survey.

Hurteau, M. D., Bradford, J. B., Fulé, P. Z., Taylor, A. H., \& Martin, K. L. (2014). Climate change, fire management, and ecological services in the southwestern US. Forest Ecology and Management, 327, 280-289. https://doi.org/10.1016/j.foreco.2013.08.007

James, J. J., Alder, N. N., Mühling, K. H., Läuchli, A. E., Shackel, K. A., Donovan, L. A., \& Richards, J. H. (2005). High apoplastic solute concentrations in leaves alter water relations of the halophytic shrub, Sarcobatus vermiculatus. Journal of Experimental Botany, 57(1), 139-147. https://doi.org/10.1093/jxb/erj016

Jensen M. E., Burman, R. D., \& Allen, R. G. (eds). (1990). Evapoptranspiration and irrigation water requirements. Am. Soc Civil Eng., 332 p.

Kolb, K. J., \& Sperry, J. S. (1999). Transport constraints on water use by the Great Basin shrub, Artemisia tridentata. Plant Cell and Environment, 22, 925-936.

Koonce, J. E. (2016). Water balance and moisture dynamics of an arid and semi-arid soil: A weighing lysimeter and field study.

Leffler, A. J., Ivans, C. Y., Ryel, R. J., \& Caldwell, M. M. (2004). Gas exchange and growth responses of the desert shrubs Artemisia tridentata and Chrysothamnus nauseosus to shallow-vs. deep-soil water in a glasshouse experiment. Environmental and Experimental Botany, 51(1), 9-19. https://doi.org/10.1016/S0098 $-8472(03) 00481-8$ 
Lin, G., Phillips, S. L., \& Ehleringer, J. R. (1996). Monosoonal precipitation responses of shrubs in a cold desert community on the Colorado Plateau. Oecologia, 106(1), 8-17. https://doi.org/10.1007/BF00334402.

McCabe, G. J., \& Wolock, D. M. (2007). Warming may create substantial water supply shortages in the Colorado River basin. Geophysical Research Letters, 34(22). https://doi.org/10.1029/2007GLO31764

Mensing, S., Strachan, S., Arnone, J., Fenstermaker, L., Biondi, F., Devitt, D., ... \& Fritzinger, E. (2013). A network for observing Great Basin climate change. Eos, Transactions American Geophysical Union, 94(11), 105-106.

Monteith, J., \& Unsworth, M. (2007). Principles of environmental physics. Academic Press.

Nichols, W. D. (1994). Groundwater discharge by phreatophyte shrubs in the Great Basin as related to depth to groundwater. Water Resources Research, 30(12), 3265-3274.

Obrist, D., Yakir, D., \& Arnone Iii, J. A. (2004). Temporal and spatial patterns of soil water following wildfire-induced changes in plant communities in the Great Basin in Nevada, USA. Plant and Soil, 262(1-2), $1-12$.

Pataki, D. E., Billings, S. A., Naumburg, E., \& Goedhart, C. M. (2008). Water sources and nitrogen relations of grasses and shrubs in phreatophytic communities of the Great Basin Desert. Journal of Arid Environments, 72(9), 1581-1593. https://doi.org/10.1016/j.jaridenv.2008.03.011

Phillips, D. L., Newsome, S. D., \& Gregg, J. W. (2005). Combining sources in stable isotope mixing models: alternative methods. Oecologia, 144(4), 520-527.

Sperry, J. S., \& Hacke, U. G. (2002). Desert shrub water relations with respect to soil characteristics and plant functional type. Functional Ecology, 16(3), 367-378.

Steinwand, A. L., Harrington, R. F., \& Or, D. (2006). Water balance for Great Basin phreatophytes derived from eddy covariance, soil water, and water table measurements. Journal of Hydrology, 329(3-4), 595-605. https://doi.org/10.1016/j.jhydrol.2006.03.013

Steinwand, A. L., Harrington, R. F., \& Or, D. (2006). Water balance for Great Basin phreatophytes derived from eddy covariance, soil water, and water table measurements. Journal of Hydrology, 329(3-4), 595-605. https://doi.org/10.1002/jgrd.50360

Toft, C. A. (1995). A 10-year demographic study of rabbitbrush (Chrysothamnus nauseosus): growth, survival and water limitation. Oecologia, 101(1), 1-12.

USSL. (1954). Diagnosis and improvement of saline and alkali soils. Ag. Handbook No. 60 USDA. Washington D.C.

Wagner, A. J. (2016). Water Source Partitioning for Shrubland Transpiration in a Mixed Phreatophytic Plant Community. M.S. Thesis. Univ. Nevada Las Vegas, School of Life Sciences.

\section{Copyrights}

Copyright for this article is retained by the author(s), with first publication rights granted to the journal.

This is an open-access article distributed under the terms and conditions of the Creative Commons Attribution license (http://creativecommons.org/licenses/by/4.0/). 